\title{
LOR Gene
}

National Cancer Institute

\section{Source}

National Cancer Institute. LOR Gene. NCI Thesaurus. Code C112145.

This gene plays a role in the structure of keratinocyte cell envelopes. 